\title{
Manajemen Berbasis Sekolah Dalam Upaya Meningkatkan Kinerja Guru Pada Smp Swasta Titfen Di Yayasan Titfen Kabupaten Kupang
}

\author{
Saul Fina ${ }^{1}$ \\ ${ }^{1}$ Dosen Program Studi Pendidikan Guru Sekolah Dasar, Universitas Karyadarma Kupang, Indonesia \\ Email: saulfina13@gmail.com
}

\begin{abstract}
This research title is; School Based Management in Strive to Improve Teacher Performance at Junior Hight School of Private Sector in Titfen Institution of Kupang Regency. Research Problem are; Why School Based Management on the selected to increase Teacher Performance at SMP Swasta Titfen? Focus this study are; (1). School Base Management on the Titfen Private Sector; (2). School based management; and (3). Teacher performance. The research methods are qualitative with the approach of symbolic interaction and fenomenologis. Researcher identified the essensial of human being experience about phenomenon and elaborated all behavior of human being which basically own the MBS meanings, starting from education phenomenon. Technique of data collection with circumstantial interview, observation and document study. Analysis data used through a data collection, reducing, data presentation and the data analysis. Result of this research showed that; (1). School base management on the private sector to make low teacher performance (2). school based management could improve the theacher performance. By school based management (SBM) is autonomous school is gone into effect, existence of tranparansy, akuntabilitas and existence of school independence in managing school; and (3). effort of increase teacher performance in SMP Titfen of Private sector. Despitefully, institution of education Titfen require to change the self and ready to accept the management of change, namely MBS, to be teacher performance can be improved so that quality of education can be improved.
\end{abstract}

Keywords : Management Yasayan, School Based Management, Strive to Improve, the Teacher Performance

Abstrak. Penelitian ini berjudul "Manajemen Berbasis Sekolah Dalam Upaya Meningkatkan Kinerja Guru Pada SMP Swasta Titfen Di Yayasan Titfen Kabupaten Kupang". Masalah Penelitian adalah ; Mengapa Manajemen Berbasis Sekolah dipilih untuk meningkatkan Kinerja Guru pada SMP Swasta Titfen? Fokus masalahnya adalah (1). Manajemen Sekolah berbasis Yayasan; (2). Manajemen Berbasis Sekolah; dan (3). Kinerja Guru. Metode penelitian kualitatif dengan pendekatan fenomenologis dan interaksi simbolis. Peneliti mengidentifikasi esensi pengalaman manusia tentang fenomena manajemen Yayasan dan MBS serta menguraikan semua perilaku manusia yang pada dasarnya memiliki makna-makna sosial (social meanings), bertolak dari fenomena yang dialami. Teknik pengumpulan data dengan wawancara mendalam, observasi dan studi dokumen. Analisis data digunakan pengumpulan data, reduksi, penyajian dan analisis data. Fokus kajiannya didasarkan pada data dan sejumlah informasi yang diperoleh dengan tidak menetapkan jumlah informan. Hasil menunjukan bahwa (1). Manajemen sekolah berbasis yayasan kinerja guru rendah; (2). Manajemen Berbasis Sekolah dapat meningkatkan kinerja guru. Dengan MBS ddiberlakukan otonomi sekolah, adanya tranparansipenelitiannya, akuntabilitas dan adanya kemandirian sekolah dalam mengelola sekolah; dan (3). Upaya meningkatkan kinerja guru adalah menerapkan MBS di SMP Swasta Titfen. Di samping itu, yayasan pendidikan Titfen perlu merubah diri dan siap menerima manajemen perubahan, yakni MBS, agar kinerja guru dapat ditingkatkan sehingga mutu pendidikan dapat ditingkatkan.

Kata Kunci : Manajemen Yasayan, MBS, Upaya Meningkatkan, Kinerja Guru 


\section{PENDAHULUAN}

Manajemen Berbasis Sekolah merupakan model pengelolaan yang memberikan otonomi yang lebih besar kepada sekolah, memberikan fleksibilitas kepada sekolah, mendorong partisipasi secara langsung dari warga sekolah dan masyarakat dalam meningkatkan mutu pendidikan. Artinya Manajemen Berbasis Sekolah merupakan proses yang mengintegrasikan sumber-sumber di sekitar sekolah yang semula satu dengan yang lainnya tidak berhubungan menjadi suatu sistem yang menyeluruh untuk mencapai tujuan sekolah secara efektif dan efisien, yaitu meningkatkan mutu pendidikan. Undang-Undang Republik Indonesia Nomor 20 Tahun 2003 tentang Sistem Pendidikan Nasional, pada bagian umum (mengingat) huruf c, menyatakan bahwa Sistem Pendidikan Nasional harus mamapu menjamin pemerataan kesempatan pendidikan, peningkatan mutu serta relevansi dan efisiensi manajemen pendidikan sekolah untuk menghadapi tantangan sesuai dengan tuntutan perubahan lokal, nasional dan global sehingga perlu dilakukan pembaharuan pendidikan secara terencana, terarah dan berkesinambungan."

Undang-Undang menjelaskan bahwa sekolah yang baik adalah sekolah yang memiliki manajemen yang efisien dan bermutu, baik dalam menghadapi tantangan perubahan atau pembaharuan pendidikan yang terencana. Dalam mencapai suatu mutu pendidikan yang diinginkan, bukan hanya dikembangkan pembangunan fisik semata, melainkan harus memprioritaskan pengembangan MBS. Pihak sekolah harus mengadakan perubahan dari kondisi sekolah yang kurang terencana, terarah dan berkesinambungan menuju arah yang lebih baik. Sekolah harus mengikuti perkembangan pendidikan yang telah dan sedang terjadi yang dapat membawa berbagai perubahan dalam dunia pendidikan. Apabila MBS lebih difokuskan pada tingkat otonomi sekolah, maka dapat menyediakan layanan pendidikan yang komperhensif dan tanggap terhadap kebutuhan masyarakat.

Melalui MBS program sekolah disusun dan direncanakan serta adanya keterbukaan dalam pengelolaan anggaran pendidikan. Misalnya, penggunaan anggaran pendidikan yang transparan, guru atau kepala sekolah yang melakukan kerjasama dengan orang tua siswa ketika terjadi masalah dengan peserta didik (Daryanto, 2013: 178). Dan jika perlu guru mengundang seorang ahli dari masyarakat untuk memberikan ceramah atau latihan-latihan dalam keterampilan tertentu (Hamalik, 2013: 117). Hal ini dapat memungkinkan terjadiya sosialisasi antara guru maupun siswa dengan masyarakat yang dapat membantu perkembangan kepribadian guru maupun siswa dalam membangun hubungan sosial di lingkungan pendidikan dengan masyarakat.

Masalah penelitian adalah bahwa selama ini sekolah-sekolah belum menjalankan MBS. Banyak sekolah tidak berkembang dikarenakan manajemen sekolah yang kurang memadai. Tidak berkembangnya sekolah tersebut juga diakibatkan oleh kepala sekolah yang kurang mengerti tentang MBS. Persoalan yang sama juga dialami oleh sekolah-sekolah yang berada di lingkungan Yayasan Lembaga Putra Timor Tefena Toh (Titfen) di Kabupaten Kupang, khususnya SMP Titfen. Manajemen pengelolaan sekolah masih sangat memprihatinkan dan tidak sesuai dengan MBS yang diinginkan, baik oleh pemerintah maupun pendidik yang melaksanakan tugas pada yayasan tersebut. Dominasi yayasan dalam pengambilan keputusan menyangkut sekolah sering menimbulkan suasana yang kurang kondusif. Setiap kali mengambil kebijakan kepala sekolah harus terlebih dahulu berkoordinasi dengan pihak yayasan untuk menyelesaikan masalah-masalah yang terjadi di sekolah. Manajemen pengelolaan semuanya berpatokan pada pihak yayasan sehingga berakibat fatal bagi kepala sekolah dalam menjalankan tugasnya. Dengan demikian, manajemen sekolah-sekolah yang bernaung di bawah Yayasan Lembaga Putra Timor Tafena Toh (Titfen) MBS-nya belum berjalan, melainkan manajemen sekolah berbasis yayasan. Yayasan berhak penuh dalam mengambil keputusan mengenai perkembangan dan perubahan sekolah, sedangkan kepala sekolah dan stakeholder hanya menuruti perintah yayasan. Hal ini sangat berpengaruh terhadap kinerja guru (Oedjoe, et.al., 2010:50). 


\section{METODE PENELITIAN}

Konteks penelitiannya adalah SMP Swasta Titfen yang berada di bawah naungan yayasan tersebut, di mana secara kasat mata manajemen yang dilakukan oleh yayasan sangat membelenggu kebebasan kepala sekolah dalam meningkatkan kinerja guru. Metode penelitian kualitatif dengan pendekatan fenomenlogi. Pendekatan fenomenologi adalah sebuah strategi penemuan dalam mana peneliti mengidentifikasi esensi dari pengalaman manusia tentang fenomena yang diuraikan oleh peneliti. Pendekatan fenomenologi digunakan untuk mengungkapkan bagaimana manajamen perubahan diterapkan dalam meningkatkan kinerja guru. Penulis akan mencoba menjejaki setiap fenomena sambil mengungkapkan makna yang tersimpan di dalamnya. Peneliti berusaha memahami bagaimana fenomena manajemen sekolah dalam kaitannya dengan kinerja guru, maka harus memahami dari sudut pandang pelaku itu sendiri.

\section{HASIL DAN PEMBAHASAN}

\section{A. Persepsi Terhadap Manajemen Yayasan Titfen}

Yayasan merupakan badan hukum yang terdiri atas kekayaan yang dipisahkan dan diperuntukan untuk mencapai tujuan tertentu di bidang sosial, keagamaan dan kemanusiaan dan tidak mempunyai anggota. Undang-Undang RI Nomor 16 Tahun 2001 tentang syarat berdirinya suatu yayasan, menyatakan bahwa yayasan merupakan salah satu bentuk badan hukum adalah sangat penting bagi organisasi. Yayasan sebagai sarana format dalam melakukan tindakan hukum dan dengan adanya yayasan, pengurus organisasi dapat bertransaksi dan bekerja sama dengan instansi pemerintah, swasta atau perorangan yang memerlukan aspek legalitas. Pada dasarnya strategi yayasan diharapkan dapat menyatukan seluruh rencana dan mengikat semua bagian menjadi terpadu. Untuk itu perlu menetapkan tujuan, visi, misi dan nilai-nilai yang akan dibudayakan dalam aktivitas yayasan dengan mempertimbangkan aspek kebersamaan.

Berbeda dengan SMP Swasta Titfen, penyelenggaraan sekolah dalam hal manajemen masih berbasis yayasan, demikian yang diungkapkan oleh Adam Y. Lona (wawancara, tanggal, 27 Juli 2015). la menyatakan bahwa dalam perencanaan, pengorganisasian, pelaksanaan dan pengawasan SMP Titfen masih ditangani yayasan Titfen. Berikut hasil penelitian mengenai persepsi guru terhadap manajemen sekolah dalam perencanaan, pengorganisasian, pelaksanaan dan pengawasan di SMP Titfen. Manajemen sekolah pada SMP Titfen berbasis yayasan. Hal ini sangat beralasan karena sekolah ini bukan sekolah negeri, melainkan sekolah yang didirikan oleh yayasan. Pernyataan ini sesuai hasil wawancara dengan ketua yayasan Titfen, Yahya Baksuni (Wawancara, 29 Juli 2015) yang menyatakan;

Sekolah ini bukan sekolah negeri dan bukan didanai oleh pemerintah, melainkan sekolah ini milik yayasan, maka paling tidak manajemen sekolah bercirikhas yayasan. Kurikulum pembelajaran memang harus disesuaikan dengan kurikulum nasional, tetapi manajemennya merupakan hak yayasan. Segala sesuatu yang berkaitan dengan sekolah ini, mulai dari perencanaan, pengelolaan dan pengontrolan dipegang dan diatur oleh yayasan. Segala kebijakan dan keputusan serta maju mundurnya sekolah ini ada di bawa kendali yayasan.

Keadaan ini membenarkan bahwa SMP Titfen merupakan milik yayasan dan tidak dapat dipungkiri bahwa yayasan memegang kendali dalam segala aktivitas manajemen persekolahan. Senada dengan itu, hasil wawancara penulis dengan Menci Seo (wawancara, 01 Juli 2015) guru agama Kristen juga menyakan hal yang sama, bahwa SMP Titfen mulai dari perencanaan, pengelolaan, pelaksanaan dan pengawasan menjadi hak penuh yayasan (wawancara, 27 Juli 2015). 
Persepsi tersebut di atas, jika ditarik benang merahnya, maka pandangan tersebut berusaha membangkitkan imajinasi guru dan masyarakat sekitar dengan pandangan utopianisme seperti yang dikemukakan oleh Schon (1985) dikutip Siswanto (2013:54) bahwa perencanakan yang dikerjakan atau direncanakan oleh atasan belum tentu diseujui atau dijalankan oleh bawahan, karena rencana tersebut kurang atau tidak sesuai dengan kondisi factual di lapangan. Dengan demikian pandangn ini bisa dibenarkan jika dikaitkan dengan kebijakan yang diambil oleh yayasan belum tentu sesuai dengan kondisi riil sekolah setiap harinya.

\section{B. Manajemen SMP Titfen Berbasis Yayasan}

Manajemen sekolah berbasis yayasan merupakan suatu manajemen pengelolaan sekolah yang dikuasai oleh lembaga atau yayasan yang bergerak di bidang pendidikan. Dalam manajemen ini, pengelolaan, kepemimpinan, pengawasan dan pembimbingan atas asset usaha yang berupa sumber daya manusia (SDM) dikuasai oleh yayasan. Artinya segala aktivitas yang berkaitan dengan menajemen sekolah berpedoman pada aturan yayasan yang mendirikannya. Dengan demikian, lembaga pendidikan yang bernaung di bawah yayasan atau yang bergerak di bidang jasa dan pelayanan publik sudah seharusnya dikelola dengan baik berdasarkan sistem manajemen yang umum digunakan dalam bidang usaha. Hasil wawancara penulis dengan Ketua Komite, Adam Y. Lona, (wawancara, 23 Juli 2015) menyatakan bahwa manajmen sekolah berbasis yayasan artinya, manajemen sekolah yang dikelola oleh yayasan. Artinya bahwa pada umumnya, lembaga yang bergerak di bidang pendidikan memiliki manajemen tertentu, yang merupakan cirikhas lembaga tersebut.

Selain itu, struktur organisasi yang digunakan secara menoton, bahkan itu-itu saja. Hasil wawancara penulis dengan Zhakarias Loleh, (wawancara 20 Juli 2015) mantan kepala sekolah SMP Titfen, menyatakan bahwa keadaan atau kondisi manajemen pada SMP Swasta Titfen itu-itu saja, kurang ada variasi dan kurang ada perubahan. Struktur organisasi yang dimiliki, misalnya; ketua yayasan, kepala sekolah, kesiswaan, wakil kepala sekolah sarana prasarana dan wakil kepala sekolah hubungan dengan masyarakat.

\section{Sistem Manajemen SMP Titfen Berbasis Yayasan}

Yayasan sekolah merupakan sebuah tempat atau lembaga berhimpun pendiri sekolah (perorangan atau kongsi/lebih dari satu orang) yang pada awalnya terpanggil untuk mengembangkan dunia pendidikan. Sistem manajemen merupakan keseluruhan proses yang terdiri dari bagian-bagian yang saling berinteraksi dalam usaha untuk mengubah masukan menjadi keluaran yang berguna bagi pendidik, tenaga kependidikan, terlebih khusus bagi peserta didik pada SMP Swasta Titfen selalu terdapat kendala.

Hasil penelitian diperoleh, terdapat beberapa masalah yang dihadapi yayasan, baik pendiri maupun pengelola yayasan, sehingga menyebabkan mutu pendidikan serta kinerja guru rendah. Bertolak dari manajemen pendidikan atau pengelolaan sekolah pada umumnya, sistem manajemen sekolah pada SMP Titfen sedikit berbeda. Keperbedaan ini terletak pada garis komando dalam pelaksanaannya, bukan pada otonomi sekolah, melainkan merupakan otonomi yayasan. Hasil wawancara penulis dengan Maria Novita Minggu (wawancara 02 Agustus 2015) seorang guru pada SMP Titfen menyatakan bahwa

Sistem pengelolaan SMP Titfen sangat kaku, yayasan terlalu aktif mencampuri urusan sekolah yang pada dasarnya merupakan kewenangan kepala sekolah. Di satu pihak pendiri/yayasan tindakan tersebut bersifat positif untuk melakukan pengawasan, tetapi di lain pihak manajemen sekolah termasuk jajaran kepala sekolah dan guru tidak dapat mengembangkan diri dengan baik. Segala keputusan masih tergantung pada yayasan. Dalam jangka panjang tindakan ini sangat melemahkan, kepala sekolah dan guru dan manajemen kehilangan kreativitasnya dan semuanya tidak berani mengambil keputusan dan keberanian untuk bertindak. 
Mundurnya atau keluar-masuknya guru sangat berdampak buruk pada SMP Titfen yang menyebabkan sekolah ini berisikan guru yang tidak sesuai dengan latar belakang pendidikan yang hanya mampu menjalankan tugas rutin sebagai guru yang selalu membicarakan kejelekan yayasan serta SMP Titfen dijadikan sebagai batu loncatan untuk menunggu peluang di sekolah lain. Hal ini juga dibenarkan oleh El Roy Abatan (wawancara, 02 Juli 2015) mantan Kepala Sekolah SMP Titfen selama 4 bulan (wawancara, 02 Januari-31 Mei 2013) bahwa "yayasan kurang peduli dengan kesejahteraan guru dan tidak menguasai masalah di sekolah".

\section{Kesejahteraan (Penggajian) Guru SMP Titfen}

Masalah terbesar yang sementara dihadapi SMP Titfen pada saat ini adalah pola penggajian atau tingkat kesejahteraan guru, khususnya guru Persoalan inilah yang menjadi salah satu fokus penelitian ini yang berhubungan langsung peningkatan kinerja guru. Berdasarkan data, saat ini guru yang mengajar di sekolah swasta Titfen berjumlah 15 orang guru dan semuanya adalah guru swasta (non PNS), dengan gaji rata-rata sekitar Rp. 400.000.- per bulan, bahkan ada guru yang gajinya antara Rp. 100.000,--Rp. 150.000.- per bulan. Sungguh gaji yang tidak layak untuk tenaga profesional yang berpendidikan S1 atau D4. Gaji ini hampir sama dengan gaji tukang batu saja per harinya Rp. 40.000.atau sekitar Rp. 1.200.000-, per bulan ddan bila yayasan tidak mampu memberi gaji sebesar UMR pendidikan, maka sangat mempengaruhi kinerja guru dalam melaksanakan tugasnya di sekolah (Haryanto, 2013 dikutip dari haryanto-jogya-blogspot, diakses 04 Oktober 2015). Hasil wawancara penulis dengan hampir semua guru menyatakan bahwa gaji yang diberikan oleh yayasan pendidikan Titfen tidak sebanding dengan ijasah yang dimiliki maupun jasa yang diberikan dalam meningkatkan mutu pendidikan.

Hasil wawancara penulis dengan Etri Nenabu (wawancara, 25 Juli 2015) mengemukakan bahwa;

Gaji kami di sini terbesar Rp.400.000,-, biar masa kerjanya sudah 10 tahun, namun gajinya tetap seperti itu. Kalaupun ada kenaikan, itupun hanya sedikit. Kami tidak mendapat tunjangan lai-lain seperti pada guru PNS, karena kami diangkat oleh yayasan dan gaji kami juga ditentukan oleh yayasan.

Pandangan ini dapat diiterpretasikan bahwa, memang benar gaji guru pada SMP Swasta Titfen gaji guru sangat rendah. Hal ini menjadi faktor utama rendahnya kinerja guru. Seperti yang telah diuraikan sebelumnya bahwa yayasan juga sangat tertutup dalam pengelolaan keuangan. Hasil wawancara penulis dengan Debrina D.Selan (wawancara 23 Juli 2015) juga menambahkan bahwa yayasan kurang tranparan dalam mengelola keuangan sekolah. Guru dan pegawai serta kepala sekolah siap menerima segala keputusan menganai keuangan sekolah, bahkan RABS sekolah pun ditentukan oleh yayasan.

\section{E. Persepsi tentang Kinerja Guru pada SMP Swasta Titfen}

Kinerja guru SMP Swasta Titfen masih sangat memperhatinkan. Dalam hal partisipasi, guruguru kurang mempunyai inisiatif dalam meningkatkan sumber daya manusia atau mengembangkan dirinya agar lebih mampu dalam melaksanakan tugasnya sebagai seorang guru profesional. Badasarkan hasil pengamatan peneliti bahwa SDM pada SMP Swasta Titfen masih sangat rendah. Hal ini dilihat dari kebanyakan guru belum memiliki sertifikat pendidik. Dalam konteks ini boleh dikatakan bahwa guru-guru SMP Swasta Titfen belalum memadai karena belum memiliki syarat profesional yang dimanatkan oleh undang-undang. Hasil wawancara peneliti dengan Maria Minggu (wawancara, 20 Juli 2015) mengemukakan bahwa kami di sini (SMP Swasta Titfen) kebanyakan barusan tamat kuliah sarjana. Artinya dilihat dari pengalaman kerja kami belum mempunyai pengalaman yang mumpuni. Hal senada juga disampaikan oleh Etri Nenabu (wawancara, 20 Juli 2015) menyatakan bahwa yayasan kurang peduli dengan pengembangan SDM guru, sehingga kami jadi tetap seperti ini, tidak pernah bersaing dengan teman-teman guru di sekolah lain. Dengan demikian, kinerja guru yang baik dan profesional dalam mengimplementasikan kurikulum, seperti 
mendesain program pembelajaran, melaksanakan pembelajaran dan menilai hasil belajar peserta didik kurang dimiliki oleh guru-guru di SMP Swasta Titfen.

Kedua, Kinerja guru mempunyai spesifikasi tertentu dan salah satunya adalah pengembangan karir. Hasil wawancara dengan Maria. Minggu (wawancara 20 Juli 2015) menyatakan bahwa k"ami sulit mengembangkan karir kami, karena gaji kami atau kesejahteraan kami sangat minim". Maksudnya bahwa guru-guru pada SMP Swasta Titfen tidak mampu mengembangkan karir karena penghasilan yang diperoleh berada di bawah rara-rata. Penghasilan mereka tidak cukup untuk kebuthan hidup apalagi mengembangkan karir. Hal senada juga diakui oleh Natalia Fetok (wawancara, 25 Juli 2015) yang menyatakan bahwa "gaji kecil, makan minum saja masih susah, baimana bisa kuliah lanjut, apalgi yayasa juga tidak medukung dengan dana, gaji saja di bayar terlambat". Keadaan ini sangat berat untuk meningkatkan kinerja guru di mana dukungan finansial tidak cukup, baik secara personal maupun dukungan dari yayasan.

Ketiga, Komunikasi yang efektif dalam suatu organisasi dapat meningkatkan kinerja kerja yang baik dalam suatu yayasan. Komunikasi yang dibangun harus berdasarkan persamaan persepsi tentang suatu rencana atau pelaksanaan untuk mencapai visi, misi dan tujuan sekolah. Pada SMP Titfen yang dikelola oleh yayasan, jarang sekali terjadi komunikasi yang efektif antara kepala sekolah, yayasan dan dewan pendidik. Garis komando yang diterapkan oleh yayasan menyebabkan dewan guru engan mempertanyakan atau mempersoalkan kinerja yayasan. Hal senada disampaikan oleh Zakarias Loleh (wawancara, 20 Juli 2015) mantan kepala sekolah menyatakan bahwa antara yayasan dan kepala sekolah kadang-kadang kurang ada komunikasi.

Keempat, Aspek insentif adalah usaha yayasan untuk memberikan motivasi kepada kepala sekolah dan guru agar terus melakukan tugas dan tanggungjawabnya dalam menyelesaikan tugastugasnya sebagai tenaga pendidik. Hasil wawancara penulis dengan Ausila D.F.Eko (wawancara, 26 Agustus 2015) menyatakan bahwa Gaji saja bayar terlambat apalagi pemberian insentif kepada guruguru". Maksudnya bahwa dalam proses penggajian, setiap guru paling lambat 2 sampai 3 bulan baru menerima gaji atau honor dari yayasan. Artinya bahwa dengan keterbatasan dana, maka yayasan tidak mampu memberi insentif kepada guru yang berprestasi atau berkinerja baik.

Kelima, Sebagai tenaga profesional, guru diharapkan dapat berfungsi dan berperan meningkatkan martabat dan agen pembelajaran. Tujuannya adalah meningkatkan mutu pendidikan nasional. Guru pada SMP Swasta mampu memaknai pembelajaran serta menjadikan pembelajaran sebagai ajang pembentukan kompetensi dan perbaikan kualitas pribadi peserta didik. Hasil wawancara peneliti dengan ketua yayasan Yahya Basuni (wawancara, 10 Juli 2015) menyatakan bahwa :

Keenam, Hasil pengamatan peneliti menemukan bahwa guru-guru pada SMP Titfen boleh dikatakan mempunyai disiplin yang baik, mereka selalu melakukan pekerjaan dan tugasnya serta menjalankan kewajiban dengan bertanggungjawab. Dari sisi prakarsa, mereka juga mempunyai ideide yang membangun. Akan tetapi kembali pada persoalan awal bahwa selalu terbentur dengan kemauan yayasan. Inovasi yang dilakukukan guru-guru pada SMP Titfen selalu tidak terealisisr karena selalu berhadapan dengan ketertutupan manajemen yayasan.

Ketujuh epemimpinan kepala sekolah pada SMP Titfen hampir kurang berfungsi. Hasil wawancara penulis dengan Marta Lefta (wawancara, 26 Juli 2015) seorang kepala Tata Usaha menyatakan bahwa hubungan kepala sekolah dengan yayasan bersifat intruksional, karena kepala sekolah harus mendengar instruksi dari pimpinan atau pengelola yayasan.

\section{F. Faktor-Faktor yang Mempengaruhi Rendahnya Kinerja Guru SMP Titfen}

Pertama, Faktor-faktor yang mempengaruhi kinerja seseorang atau individu antara lain lingkungan, perilaku manajemen, desain jabatan, penilaian kerja, umpan balik dan administrasi pengupahan. Lebih lanjut Mulyasa (2004:12-13) mengemukakan bahwa terdapat beberpa faktor yang mempengaruhi kinerja guru, yaitu (1). keterapmpilan dan kemampuan mental dan fisik; (2). latar belakang keluarga; tingkat sosial; pengalaman; (3). demografis; umur, etnis,jenis kelamin. 
Sedangkan aspek kemampuan meliputi kemampuan memahami kurikulum dan menjabarkannya dalam proses pembelajaran.

Kedua, Masalah terbesar yang sementara dihadapi SMP Titfen pada saat ini adalah pola penggajian atau tingkat kesejahteraan guru, khususnya guru. Gaji guru rata-rata sekitar Rp. 400.000.per bulan, bahkan ada guru yang gajinya antara Rp. 100.000,--Rp. 150.000.- per bulan. Sungguh gaji yang tidak layak untuk tenaga profesional yang berpendidikan S1 atau D4. Gaji ini hampir sama dengan gaji tukang batu saja per harinya Rp. 40.000.- atau sekitar Rp. 1.200.000-, per bulan dan bila yayasan tidak mampu memberi gaji sebesar UMR pendidikan, maka sangat mempengaruhi kinerja guru dalam melaksanakan tugasnya di sekolah.

\section{G. Tujuan Manajemen Berbasis Sekolah}

Yayasan Titfen yang bergerak dalam dunia pendidikan perlu memahami manajemen berbasis sekolah. Lebih rincinya MBS bertujuan untuk; (1). meningkatkan mutu pendidikan melalui kemandirian dan inisiatif sekolah dalam mengelola dan memperdayakan sumber daya yang tersedia; (2). meningkatkan kepedulian warga sekolah dan masyarakat dalam penyelenggaraan pendidikan melalui pengambilan keputusan bersama; (3). meningkatkan tanggungjawab sekolah kepada orang tua, masyarakat dan pemerintah tentang mutu sekolah; dan (4). meningkatkan kompotensi yang sehat antar sekolah tentang mutu pendidikan yang akan dicapai (Mustari, 2014:9).

Hasil wawancara dengan hampir semua guru bahwa mereka menyambut baik dan bahkan menyatakan sebaiknya MBS diterapkan di SMP Swasta Titfen. Demikian hasil wawancara dengan Lodwyk Langke (58thn, wawancara, 24 Juli 2015) yang dibahasakan ulang oleh peneliti, menyatakan bahwa dengan melakasanakan MBS keberhasilan sekolah dapat tercapai, karena keberhasilan ditentukan oleh semua komponen yang ada di dalamnya. Komponen sekolah yang tak berfungsi dengan baik akan mempengaruhi keberhasilan pencapaian tujuan sekolah. Selain itu, hasil wawancara penulis dengan Ausalia Dora (wawancara, 04 Sepetember 2015) mengemukakan bahwa kinerja sekolah diukur melalui efektivitasnya, kualitasnya, produktivitasnya, efisiensinya, inovasinya, kualitas kehidupan kerjanya, surplusnya dan moral kerjanya

Berdasarkan argumentasi tersebut, penulis menarik benang merahnya bahwa karakteristik proses manajemen sekolah yang efektif dapat dilihat dari; Pertama, perencanaan dan pengembangan sekolah dimana perencanaan yang baik di sekolah menggambarkan kehendak yang kuat dari pihak sekolah untuk mencapai sesuatu yang ideal di masa depan; Kedua, iklim dan budaya sekolah. Iklim dan budaya sekolah yang kondusif menjamin proses belajar siswa. Iklim dan budaya sekolah yang kondusif sangat penting agar siswa merasa tenang, aman dan bersikap positif terhadap sekolah, agar guru merasa dihargai, orangtua dan masyarakat merasa dirinya diterima dan dilibatkan. Iklim dan budaya sekolah juga berkaitan dengan penuturan harapan untuk berprestasi pada semua personil sekolah; Ketiga, pemantapan terhadap kemajuan siswa. Hal ini penting untuk merencanakan siasat pembelajaran, mengubah metode atau menambah serta mengurangi beban kerja.

Keempat, kepemimpinan Kepala Sekolah, dimana kepemimpinan kepala sekolah sangat berpengaruh terhadap prestasi akademik dan semua aspek kinerja sekolah; Kelima, Pengembangan Guru dan Staf. Pengembangan guru dan staf perlu dilakukan untuk memastikan bahwa mereka tetap dapat mempertahankan kualitas profesinalismenya sesuai dengan kebutuhan sekolah; Keenam Pengembangan Kesiswaan. Pengembangan kesiswaan mencakup dua aspek penting yaitu keterlibatan siswa dalam kehidupan sekolah dan layanan-layanan yang diberikan dalam rangka pengembangan kapasitas siswa. Keterlibatan siswa dalam kehidupan sekolah mempunyai korelasi dengan prestasi akademik siswa; Ketujuh, Pemberdayaan orangtua dan masyarakat dalam kegiatan sekolah keterlibatan orangtua dan masyarakat merupakan stimulasi eksternal yang memainkan peran penting bagi peningkatan kualitas pembelajaran di sekolah. Orangtua siswa dapat dianggap sebagai perwakilan para pemakai jasa pendidikan yang dapat mempengaruhi sekolah menjadi efektif; Kedelapan, Penghargaan dan Insentif. Pemberian penghargaan merupakan strategi motivasi yang penting untuk meningkatkan citra diri siswa dan guru dan berkembangnya atmosfir yang 
bersahabat dan suportif; Kesembilan, Tata Tertib dan Kedisiplinan. Karakteristik tata tertib dan kebijakan disiplin sekolah mempunyai hubungan yang signifikan dengan prestasi akademik siswa dan guru; Kesepuluh, Pengelolaan Kurikulum Sebagai inti dari program pendidikan pelaksanaan kurikulum mempunyai kaitan erat dengan prestasi belajar siswa.

\section{H. Penerapan Manajemen Berbasis Sekolah (MBS) di SMP Titfen}

Manajemen berbasis sekolah dapat bermakna adalah desentralisasi yang sistematis pada otoritas dan tanggung jawab tingkat sekolah untuk membuat keputusan atas masalah signifikan terkait penyelenggaraan sekolah dalam kerangka kerja yang ditetapkan oleh pusat terkait tujuan, kebijakan, kurikulum, standar, dan akuntabilitas. Perlu diadakan pelatihan dalam bidang-bidang seperti dinamika kelompok, pemecahan masalah dan pengambilan keputusan, penanganan konflik, teknik presentasi, manajemen stress, serta komunikasi antarpribadi dalam kelompok. Pelatihan ini ditujukan bagi semua pihak yang terlibat di sekolah dan anggota masyarakat, khususnya pada tahap awal penerapan MBS.

Untuk memenuhi tantangan pekerjaan, kepala sekolah kemungkinan besar memerlukan tambahan pelatihan kepemimpinan. Penerapan MBS mensyaratkan yang berikut; (1). MBS harus mendapat dukungan staf sekolah; (2). MBS lebih mungkin berhasil jika diterapkan secara bertahap; (3). staf sekolah harus memperoleh pelatihan penerapannya, pada saat yang sama juga harus belajar menyesuaikan diri dengan peran dan saluran komunikasi yang baru; (4). harus disediakan dukungan anggaran untuk pelatihan dan penyediaan waktu bagi staf untuk bertemu secara teratur; dan (5). yayasan harus mendelegasikan wewenang kepada kepala sekolah, dan kepala sekolah selanjutnya berbagi kewenangan ini dengan para guru dan orang tua murid.

\section{Upaya Meningkatkan Kinerja Guru pada SMP Swasta Titfen melalui MBS}

Hasil wawancara dengan Zhakarias Loleh (wawancara, 12 Juli 2015) mengemukakan bahwa MBS memiliki cakupan seperti, memberikan kewenangan sekolah dalam merekrut tenaga guru, merekrut dan mengangkat kepala sekolah, sistem pembayaran gaji, penetapan kalender sekolah, penetapan biaya pendidikan di sekolah dan juga kukrikulum yang merupakan kewenangan sekolah. Oleh karena itu supaya manajemen sekolah berjalan dengan baik yayasan tidak perlu terlalu banyak mengurusi sekolah. Hal yang sama diungkapkan oleh Maria N.Minggu (wawancara, 20 Agustus 2015) menyatakan bahwa salah satu bagian dari MBS yang dijalankan adalah kewenangan kepala sekolah dalam mengatur, merencanakan dan mengelola pendidikan di sekolah dengan baik dan benar.

Yayasan perlu menyadari batasan kewenangannya, baik di yayasan maupun di sekolah. Oleh karena itu, maka yayasan pelu membagikan kewenangan yang jelas antara mengurus yayasan secara internal dan manajemen sekolah. Hasil wawancara penulis dengan Mariana Seran (wawancara, 23 Juli 2015) mengemukakan bahwa yayasan dalam membuat keputusan harus melibatkan sekolah dan kepala sekolah. Artinya kepala sekolah dan guru diberikan kewenangan untuk mengabil keputusan berkaitan dengan manajemen sekolah terlepas dari manajemen yayasan. Jika terjadi pembagian kewenagan yang jelas maka, MBS dilaksanakan oleh kepala sekolah berdasarkan pada empat prinsip, yaitu: Pertama, prinsip ekuifinalitas (prinsiple of equifinality). Prinsip ini berasumsi bahwa terdapat beberapa cara yang berbeda-beda untuk mencapai tujuan. Praktik dari tujuan sekolah mampu memecahkan permasalahan dengan cara yang paling tepat dan sesuai dengan situasi kondisinya. Cara penanganan masalah pada setiap sekolah tentunya berlainan; Kedua, prinsip desentralisasi (principle of Decentralization). Prinsip desentralisasi ini konsisten dengan prinsip ekuifinalitas dimana sekolah diberi ruang yang lebih luas untuk bergerak, berkembang dan bekerja menurut strategistrategi unik mereka untuk menjalani dan mengelola sekolahnya secara efektif.

Ketiga, prinsip pengelolaan mandiri. Hasil wawancara dengan Marten Noberian (wawancara, 20 Juli 2015) mengemukakan bahwa sekolah harus diberikan otonomi oleh yayasan untuk mengembangkan tujuan pengajaran, strategi manajemen, distribusi sumber daya manusia dan sumber daya lainnya, memecahkan masalah dan mencapai tujuan bedasarkan kondisi mereka masing-masing. Karena sekolah dikelola secara mandiri maka mereka lebih memiliki inisiatif dan tanggung jawab; dan Keempat, prinsip inisiatif manusia (Principle of Human Initiative). Prinsip ini 
mengakui bahwa manusia bukanlah sumber daya yang statis melainkan dinanis. Oleh karena itu, potensi sumber daya manusia harus selalu digali, ditemukan dan kemudian dikembangkan. Prinsip ini sejalan dengan pendekatan human resources development, dimana sumber daya manusia dalam lembaga pendidikan harus dipandang sebagai aset penting dan mempunyai potensi untuk berkembang.

\section{J. Perubahan Pengelolaan Sekolah dari Yayasan ke Sekolah}

MBS merupakan pardigma baru yang memberikan otonomi yang luas pada sekolah agar dapat meningkatkan kinerja guru dengan baik. MBS mengubah sistem pengambilan keputusan dan manajemen dari tingkat nasional ke tingkat lokal atau dari yayasan Titfen ke pengelola sekolah, agar sekolah SMP Titfen dapat mengantarkan sekolah menjadi sekolah efektif dalam kerangka kebijakan pendidikan nasional. Otonomi diberikan oleh yayasan, agar sekolah leluasa mengelola sumber daya, dana dan mengalokasikannya sesuai dengan prioritas kebutuhan secara lebih tanggap terhadap kebutuhan lokal. Hasil wawancara penulis dengan El Roy (wawancara, 20 Agustus 2015) menyatakan bahwa

Sudah saatnya yayasan tidak boleh kaku dengan manajemen yayasan. Yayasan sudah sepatutnya merubah mindset dengan memberikan manajemen sekolah kepada kepala sekolah untuk mengelola sekolah. Yayasan perlu memberikan otonomi kepada sekolah, agar kepala sekolah dengan warga sekolah mengelola sekolah sesuai ddengan tujuan pendidikan nasional Misalnya, Manajemen Berbasis Sekolah yang responsif gender, di mana manajemen sekolah yang memberikan otonomi lebih besar kepada kepala sekolah untuk mengelola sumber daya dalam meningkatkan partisipasi langsung laki-laki dan perempuan sebagai warga sekolah guna meningkatkat mutu sekolah yang transparan, demokratis tanpa diskriminatif dan mampu bertanggungjawab kepada masyarakat (Oedjoe, et.al., 2010:50).

\section{K. Sekolah Berbasis Swakelola dan Sekolah Berbasis Penentuan Nasib Sendiri}

Mencermati pentingnya Manajemen Berbasis Sekolah dengan menyadur pandangan Oedjoe, et.al., (2010:48-49) mengatakan bahwa untuk melaksanakan MBS perlu memperhatikan usnsurunsur sebagai berikut; (1). Ketenagaan, di mana adanya kepala sekolah, pendidik dan pengawas yang berwibawa, penuh dedikasi dan berilmu dalam membimbing dan mengevaluasi setiap program yang berkaitan dengan manajemen sekolah maupun terhadap peserta didik; (2). Dana, yakni dana berasal dari APBN (BOS), APBD dan dari orang tua. Dana tersebut harus dikelola dengan transparan dan pebuh tanggungjawab (3). Kurikulum, di mana mata pelajaran inti dan muatan lokal yang dilanjutkan dalam Silabus dan RPP harus diimplementasikan dalam proses pembelajaran dan harus ada bahan ajar; (4). lingkungan sekolah yang terdiri dari lingkungan fisik, di mana sekolah harus mempunyai fasilitas yang lengkap, ruang belajar dan sebagainya dan non fisik; harus tercipta budaya sekolah yang tertib dan aman; (5). partisipasi masyarakat, yakni adanya partisipasi komite dan orang tua yang selalu peduli dengan keadaan sekolah; dan (6). manajemen sekolah, yakni sekolah harus mempunyai visi dan misi, regulasi dan harus adanya monitoring yang jelas baik dari kepala sekolah terhadap guru, maupun dari peihak pengawas serta pihak-pihak yang terkait.

\section{Tujuan Penerapan MBS di SMP Swasta Titfen}

Ada enam karakteristik organisaasi pembelajaran, yaitu; (1). adanya keberadaan visi yang dituju dan disetujui oleh seseorang; (2). orang yang meninggalkan cara pemikiran lama dan rutin baku untuk memecahkan masalah atau melakukann pekerjaan; (3). Anggota menganggap semua proses, kegiatan, fungsi dan hubungan dengan lingkugan merupakan bagian dari system antarhubungan; dan (5). Orang melakukan komunikasi secara terbuka dengan yang lainya (melalui lintas batas vertikal dan horizontal) tanpa rasa takut akan kritikan dan tekanan; dan (6). Orang memperhalus kepentingan pribadinya dan meninggalkan kepentingan departemen agar mampu bekerja bersama mencapai visi yang diharapkan. Organisasi pembelajaran merupakan obat bagi tiga masalah mendasar yang tertanam dalam organisasi tradisional yaitu; (1). fregmentasi yang 
didasarkan pada spesialisasi menciptakan dinding-dinding dan cerobong-cerobong yang memisahkan fungsi-fungsi berbeda dan menjadi raja-raja kecil yang mandiri dan sering cakar-cakaran; (2). Tekanan yang berlebihan pada persaingan sering menghancurkan kerja sama; dan (3). Kereaktifan salah mengarah perhatian manajemen kepemecahan masalah bukan ke penciptaanya (Hamlik, 2012:24).

Hasil wawancara penulis dengan semua guru mengatakan bahwa dengan adanya MBS, kepala sekolah diberikan kewenangan untuk mengelola sekolah. Kewenangan tersebut dapat dilihat dalam bagaimana kepala sekolah mengelola organisasi pembelajaran, yaitu: (1). menerapkan strategi. Menajemen Berbasis Sekolah perlu mengeksplisitkan komitmennya terhadap perubahan, inovasi dan perbaikan yang terus-menerus; (2). merancang ulang struktur organisasi. Struktur formal dapat merupakan rintangan yang serius unutk pembelajaran. Dengan mendatarkan struktur organisasi, menyingkirkan atau menggabungkan departemen-departemen, dan menimngkatan penggunaan tim lintas fungsi, maka berkurang kesaling tergantungan menguat dan tapal-batas angtara orang-oranng berkurang; dan (3). membentuk ulang budaya organisasi. Organisasi pembelajaran yang dicirikan oleh pengambilan resiko, keterbukaan dan pertumbuhan dapat dikembangangkan melalui budaya organisasi. Menajemen menentukan nama budaya aorganisasi lewat apa yang ditetapkan (strategi) maupun apa yang dilakukan (perilaku).

Kedua, sistem Manajemen Pengetahuan; Manajemen pengetahuan merupakan proses perorganisasian dan pendistribusian kebijaksanaan kolektif organisasi sehingga informasi yang tepat samapai pada orang yang tepat dan pada saat yang tepat, menjemen pengetahuan memberikan kepada organisasi keunggulan bersaing, dan sekakligus meningkatkan kinerja organisasi karena menejemen pengetahuan membuat karyawan menjadi lebih cerdas. Ada tiga alasan penting manajemen pengetahuan dalam sebuah organisasi pendidikan, yaitu; (1). Dalam banyak organisasi, aset intelektual sama pentingnya dengan aset fisik atau finansial; (2). Kekayaan Pengetahuan akan hilang jika tidak ada upaya untuk menangkapnya; dan (3). Sistim manajemen pengetahuan dirancang dengan baik akan mengurangi redundance dan membuat organisasi menjadi lebih efisien. Proses manajemen pengetahuan dalam sebuah organisasi dapat dimulai dari proses identifikasi hubungan pengetahuan dengan organisasi.

\section{Strategi Peningkatan Kinerja Guru Melalui Penerapan MBS}

Konsep MBS merupakan kebijakan baru yang sejalan dengan paradigma desentraliasi dalam pemerintahan. Strategi apa yang diharapkan agar penerapan MBS dapat benar-benar meningkatkan mutu pendidikan. Salah satu strategi adalah menciptakan prakondisi yang kondusif untuk dapat menerapkan MBS, yakni;

1. Peningkatan kapasitas dan komitmen seluruh warga sekolah, termasuk masyarakat dan orangtua siswa. Upaya untuk memperkuat peran kepala sekolah harus menjadi kebijakan yang mengiringi penerapan kebijakan MBS. Hasil wawancara penulis dengan Natalia Fetok (wawancara, 20 Agustus 2015) mengungkapkan bahwa ketika yayasan membiarkan atau meberikan otonomi kepada sekolah untuk mengelola sekolah, maka kinerja guru akan berjalan dengan baik. Oleh karena itu, yayasan harus sadar dan dengan cepat tanggap meningkatkan komitmennya kepada sekolah demi peningkatan kinerja guru. Strategi yayasan harus berubah dengan siap menerima manajemen perumabahan yang diatawarkan melalui MBS.

2. Membangun budaya sekolah (school culture) yang demokratis, transparan, dan akuntabel. Termasuk membiasakan sekolah untuk membuat laporan pertanggungjawaban kepada masyarakat. Model memajangkan RAPBS di papan pengumuman sekolah yang dilakukan oleh Managing Basic Education (MBE) merupakan tahap awal yang sangat positif. Juga membuat laporan secara insidental berupa booklet, leaflet atau poster tentang rencana kegiatan sekolah. Alangkah serasinya jika kepala sekolah dan ketua Komite Sekolah dapat tampil bersama dalam media tersebut.

3. Yayasan lebih memainkan peran monitoring dan evaluasi. Dengan kata lain, pemerintah pusat dan pemerintah daerah perlu melakukan kegiatan bersama dalam rangka monitoring dan 
evaluasi pelaksanaan MBS di sekolah, termasuk pelaksanaan block grant yang diterima sekolah.

4. Mengembangkan model program pemberdayaan sekolah. Bukan hanya sekedar melakukan pelatihan MBS, yang lebih banyak dipenuhi dengan pemberian informasi kepada sekolah. Model pemberdayaan sekolah berupa pendampingan atau fasilitasi dinilai lebih memberikan hasil yang lebih nyata dibandingkan dengan pola-pola lama berupa penataran MBS.

\section{N. MBS Sebagai Pilihan Dalam Meningkatkan Kinerja Guru}

Terdapat beberapa aspek MBS yang berkenaan dengan pilihan atau upaya meningkatkan kinerja guru yang dikemukan oleh Rohiat (2010:58-59) antara lain; Pertama, Kepemimpinan Sekolah yang kuat. Pada sekolah yang menerapkan MBS, kepala sekolah memiliki peran yang kuat dalam mengoordinasikan, menggerakan dan menyerasikan semua sumber daya pendidikan yang tersedia. Hasil wawancara penulis dengan Zhakarias Loleh (wawancara, 26 Juli 2015) mengemukan bahwa dengan MBS kepemimpinan kepala sekolah dapat mendorong sekolah untuk dapat mewujudkan visi, misi, tujuan, dan sasaran sekolahnya melalui program-program yang dilaksanakan secara terencana dan bertahap. Oleh karena itu, yayasan perlu memberikan kewenangan kepada kepala sekolah. selain itu, kepala sekolah dituntut memiliki kemampuan manajemen dan kepemimpinan yang tangguh agar mampu mengambil keputusan dan inisiatif prakarsa untuk meningkatkan mutu sekolah. Secara umum, kepala sekolah yang tangguh memiliki kemampuan memobilisasi sumber daya sekolah, terutama sumber daya manusia, untuk mencapai tujuan sekolah.

Kedua, Iklim dan Budaya Sekolah. Pilihan guru-guru untuk dilaksanakan MBS karena dapat menciptakan Iklim sekolah yang kondusif. Iklim dan budaya sekolah yang kondusif menjamin proses belajar siswa. Menurut Norce Tasewab (wawancara 26 Juli 2015) mengatakan bahwa iklim dan budaya sekolah yang kondusif sangat penting agar siswa merasa tenang, aman dan bersikap positif terhadap sekolah, agar guru merasa dihargai dan agar orangtua dan masyarakat merasa dirinya diterima dan dilibatkan. Iklim dan budaya sekolah juga berkaitan dengan penuturan harapan untuk berprestasi pada semua personil sekolah yang pada akhirnya dapat meningkatkan kinerja guru. Lebih lanjut Menci Seo (wawancara, 26 Juli 2015) mengatakan bahwa sekolah memiliki lingkungan (iklim) belajar yang aman, tertib dan nyaman sehingga proses belajar mengajar dapat berlangsung dengan nyaman (enjoyable learning). Karena itu, sekolah yang efektif selalu menciptakan iklim sekolah yang aman, nyaman dan tertib melalui pengupayaan faktor-faktor yang dapat menumbuhkan iklim tersebut. dalam hal ini, kepala sekolah memegang peranan yang sangat penting.

Ketiga, Pengelolaan Tenaga Kependidikan yang Efektif. Dengan adanya MBS pengelolaan tenaga kependidikan dapat diperhatikan melalui analisa kebutuhan, perencanaan, pengembangan dan evaluasi kinerja guru, hubungan kerja sehingga imbal jasa merupakan faktor terpenting dalam peningkatan kinerja guru. Keempat, adanya MBS sekolah memiliki budaya mutu. Maksunya bahwa setiap warga sekolah menyadari profesionalisme. Hasil wawancara dengan Menci Seo (wawancara, 27 Juli 2015) mengemukakan bahwa dengan adanya MBS terdapat kerjasama antar warga sekolah dan warga sekolah merasa aman kerana terdapat saling pengertian satu sama lain, berbeda dengan intriksi dari yayasan yang bersifat menekan.

Kelima, Penghargaan dan Insentif. Melalaui MBS, pemberian penghargaan merupakan strategi motivasi yang penting untuk meningkatkan citra diri guru dan berkembangnya atmosfir yang bersahabat dan suportif. Hasil wawancara dengan semua guru dan mereka sependapat bahwa MBS merupakan pola manajemen yang baik, karena dengan MBS pengelolaan keuangan diatur oleh kepala sekola dan transparan, berbeda dengan pengelolaan keuangan yang dilakukan oleh yayasan yang tertutup bagi warga sekolah.

Keenam, Pengelolaan Kurikulum. dengan MBS program pendidikan pelaksanaan kurikulum mempunyai kaitan erat dengan prestasi belajar siswa. Menurut Townsend (1994) pelaksanaan kurikulum mencakup isi, kualitas program yang diberikan, keterlibatan guru dalam pembelajaran, harapan masyarakat, sekolah, teknik motivasi untuk memenuhi harapan itu, alokasi waktu, tipe pembelajaran, pemantauan kemajuan belajar, tingkat keterlibatan siswa dalam pembelajaran dan 
fasilitas yang disediakan oleh sekolah. Ketujuh, Akuntabilitas Sekolah. MBS memberikan akuntabilitasi sekolah berhubungan dengan pertanggungjawaban sekolah terhadap stakeholders sekolah. Akuntabilitas pendidikan itu berdasar pada tiga prinsip, yaitu pemberitahuan, transparansi dan kesesuaian.

Kedelapan, MBS memberikan otonomi kepada sekolah untuk mengelola sekolah dengan kemandiriannya. Mariana Seran (wawancara, 28 Juli 2015) mengemukan bahwa MBS memberikan otonomi seluas-luanya kepadda sekolah untuk mengelola sekolah. Berbeda dengan manajemen sekolah berbasis yayasan di mana pengelolaan sekolah dilakukan oleh yayasan. Artinya yayasan memegang kendali pengelolaan sekolah. Hal ini tidak berlaku dalam MBS karena sekolah mengurus dirinya sendiri. Selain itu dari sisi input pendidikan, sekolah memiliki kebijakan sendiri dan tidak tergantung pada yayasan. MBS memberikan kewenangan kepada sekolah untuk mengelola komponen masukan terdiri atas masukan mental yaitu siswa. Masukan instrumental adalah kurikulum, sarana/prasarana, guru dan staf, keuangan dan organisasi. Masukan lingkungan terdiri atas dukungan orangtua, masyarakat, dan pemerintah. Sedangkan komponen hasil (outcome) merupakan perwujudan hasil belajar dalam hal keberhasilan lulusan melanjutkan pendidikan ke jenjang berikutnya atau memasuki dunia kerja.

\section{O. MBS meningkatkan Kesejahteraan Guru dan Kinerja Guru}

Gaji atau kesejahteraan guru merupakan titik sentral maju mundurnya sebuah bahtera pendidikan di Indonesia. Femomena menarik adalah semakin guru dituntuk berkinerja baik, semakin pula guru tak bergaji (dibaca gaji rendah). Yang dimaksudkan gaji rendah di sini adalah guru-guru honor yang mengabdi baik pada sekolah swasta ataupun negeri. Sebelum beranjak ke kerangka berpikir, pada kajian ini, penulis membatasi diri pada MBS dalam kaitan dengan mengapa kinerja guru pada SMP Swasta Titfen sangat rendah. Apakah ini kesalahan yang berasal dari guru atau kesalahan dalam manajemen sekolah atau akibat dari manajemen otoriter yang dibangun oleh Yayasan Pendidikan Titfen Toh. Bertolak dari analisis teori yang telah dikemukakan bahwa kinerja guru sangat dipengaruhi oleh manajemen organisasional dalam pengelolaan sekolah. Hal ini dimaksudkan untuk selain meningkatkan mutu pendidikan, juga dalam hal ini meningkatkan kinerja guru. Hasil wawancara penulis dengan Zhakarias Loleh dan Margaritha Basuni (wawancara, 26 Juli 2015) menyampaikan bahwa

Gaji guru/kesejahteraan guru kaitannya sangat erat dengan kinerja guru. Lebih lanjut merka mengemukakan bahwa Peningkatakan mutu pendidikan berhubungan erat dengan kinerja guru, dimana jika kinerja guru baik, maka sangat memungkinkan mutu pendidikan akan meningkat.

Oleh karena itu, diperlukan manajemen sekolah yang baik dalam pengelolaan sebuah sekolah yang dimulai dari perencanaan sampai pada output yang dihasilkan yang adalah cerminan dari kinerja guru yang baik (Sanjaya, 2008:215). Guru yang memiliki kinerja yang baik dan profesional dalam implementasi kurikulum dengan sendirinya meningkakan mutu pendidikan. Dengan demikian pengelolaan keuangan yang baik dalam pembayaran upah guru menjadi salah satu faktor dalam meningkatkan kinerja guru. Oleh karena itu, MBS, khususnya sekolah mengelola keuangan sendiri dalam membayar gaji guru secara tidak langsung dapat meningkatkan prestasi kerja guru.

\section{KESIMPULAN}

Bertolak dari hasil analisis data dan pembahasan hasil penelitian dengan judul "Manajemen Berbasis Sekolah dalam Upaya Meningkatkan Kinerja Guru pada SMP Swasta Titfen, maka ditarik beberapa kesimpulan sebagai berikut: (1). Manajemen sekolah berbasis yayasan kinerja guru rendah karena yayasan terlalu kaku dalam mengelola dana yang mengakibatkan kesejahteraan guru kurang diperhatikan dan pada akhirnya menyebabkan rendahnya kinerja guru; (2). Kesejahteraan guru pada SMP Titfen sangat atau kurang diperhatikan oleh yayasan Titfen dengan pola penggajian yang sangat 
buruk, yakni gaji guru hanya berkisar Rp. 300.000,- dan dibayar setiap tiga bulan sekali; (3). Bertolak dari rendahnya gaji guru pada point 2 menyebabkan kinerja guru sangat rendah pada SMP Swasta Titfen; (4). MBS dapat meningkatkan kinerja guru, karena sekolah diberikan otonomi untuk mengelola sekolah termasuk dapat meningkatkan kesejahteraan guru, di mana sekolah dapat mengelola dana sendiri sesuai dengan kebutuhan sekolah; dan (5). Penerapan MBS yang dengan pola otonomi sekolah dapat meningkatkan kinerja guru;

\section{DAFTAR PUSTAKA}

Alma, Buchari, H., 2014, Pengantar Bisnis, Bandung: Alfhabeta

Apriliya, Seni, 2007, Manajemen Kelas Untuk Menciptakan Iklim Belajar yang Kondusif, Jakarta: Visindo Media Persada.

Arikunto, Suharsimin, 2012, Dasar-Dasar Evaluasi Pendidikan, Jakarta: Bumi Aksara

Danim, Sudarwan, 2012, Visi Baru Manajemen Sekolah dari Unit Birokrasi ke Lembaga Akademik, Jakarta: Bumi Aksara

Daryanto, 2013, Konsep Dasar Manajemen Pendidikan di Sekolah, Jakarta: Gava Media

Departemen Pendidikan Nasional, 2003, Undang-undang Republik Indonesia Nomor 20 Tahun 2003 tentang Sistim Pendidikan Nasional, Jakarta

2005, Undang-undang Republik Indonesia Nomor 14 Tahun 2005 tentang Guru dan Dosen.Jakarta

Evans, R., 1996, The Human Side of School Change: Reform, Resistance, and the Real Life Problems of Innovation, San Francisco, Jose Bass.

Fattah, Nanang, 2002, Ekonomi dan Pembiayaan Pendidikan, Bandung: Remaja Rosdakarya 